\title{
Leukemia cutis and other dermatological findings in pediatric patients with acute myeloid leukemia
}

\author{
Juan A. Godínez-Chaparro' ${ }^{1}$ Adriana M. Valencia-Herrera², Mario R. Duarte-Abdala ${ }^{3}$, \\ Carlos A. Mena-Cedillos², and Mirna E. Toledo-Bahena2*
}

${ }^{1}$ Servicio de Dermatología Pediátrica, Unidad Médica de Alta Especialidad del Hospital General Dr. Gaudencio González Garza, Centro Médico Nacional la Raza, Instituto Mexicano del Seguro Social, Mexico City; ${ }^{2}$ Servicio de Dermatología Pediátrica, Hospital Infantil de México Federico Gómez, Mexico City; ${ }^{3}$ Servicio de Dermatología, Hospital del Niño y del Adolescente Morelense, Emiliano Zapata, Morelos. Mexico

\begin{abstract}
Background: Leukemia cutis (LC) is the infiltration of neoplastic leukocytes into the skin, causing skin lesions. In children, it appears more frequently in patients with acute myeloblastic leukemia (AML), particularly in subtypes with a monocytic component. Methods: We studied a retrospective cohort including all AML cases from the Hospital Infantil de México Federico Gómez between January 2009 to December 2019 and described the clinical characteristics of those who presented LC and other mucocutaneous manifestations. The information was collected from clinical records and analyzed using SPSS software (version 17). Results: We identified 54 AML cases: $53.7 \%$ were males, and $75.9 \%$ of the patients presented at least one dermatosis in the course of the disease. LC was clinically present in $14.8 \%$ of patients and was histologically confirmed in $9.2 \%$ of them; two congenital leukemia cases were identified. Among these patients, LC was more frequent in males. $L C$ patients were younger than those without $L C$, the most frequent $A M L$ subtype was $M 2(37.5 \%)$, and the most frequent clinical manifestations were plaques, chloromas, and gingival hyperplasia. None of the patients presented LC before AML diagnosis. Conclusions: Currently, only a few studies about $L C$ on pediatric populations have been reported, and the existing ones have small sample sizes. We found clinical and epidemiological similarities with other populations in the studied sample.
\end{abstract}

Keywords: Leukemia cutis. Cutaneous leukemia. Pediatric cutaneous leukemia. Acute myeloid leukemia.

\section{Leucemia cutis y otras manifestaciones dermatológicas en pacientes pediátricos con leucemia mieloide aguda}

\section{Resumen}

Introducción: La leucemia cutis (LC) es la infiltración de leucocitos neoplásicos a la piel que provoca lesiones cutáneas. En la población infantil aparece con más frecuencia en pacientes con leucemia mieloblástica aguda (LMA), principalmente en los subtipos con componente monocítico. Métodos: Se estudió una cohorte retrospectiva en el Hospital Infantil de México Federico Gómez entre enero de 2009 y diciembre de 2019 para conocer las características clínicas de los pacientes con LMA que cursaron con LC y otras manifestaciones mucocutáneas. La información se recabó de los expedientes clínicos y se analizó con el programa estadístico SPSS versión 17. Resultados: Se identificaron 54 casos de LMA: el 53.7\% en el

Correspondence:

*Mirna E. Toledo-Bahena

E-mail: mirnatoledo@gmail.com
Date of reception: $14-11-2020$

Date of acceptance: 12-04-2021

DOI: 10.24875/BMHIM.20000370
Available online: 17-09-2021

Bol Med Hosp Infant Mex. 2021;78(5):411-417

www.bmhim.com

1665-1146/@ 2021 Hospital Infantil de México Federico Gómez. Published by Permanyer. This is an open access article under the CC BY-NC-ND license (http://creativecommons.org/licenses/by-nc-nd/4.0/). 
sexo masculino y el $46.3 \%$ en el sexo femenino. El $75.9 \%$ de los pacientes presentaron alguna dermatosis durante el curso de su enfermedad. La LC se presentó clínicamente en el $14.8 \%$ de los pacientes y se confirmó histológicamente en el 9.2\% de ellos; dos casos correspondieron a leucemia congénita. De estos pacientes, la LC fue más frecuente en el sexo masculino, los pacientes fueron más jóvenes que el grupo sin LC, el subtipo de LMA más frecuente fue el M2 (37.5\%) y las principales manifestaciones clínicas fueron placas infiltradas, cloromas e hiperplasia gingival. Ninguno de los pacientes presentó $L C$ antes del diagnóstico de LMA. Conclusiones: Hasta ahora existen pocos estudios de $L C$ en las diferentes variedades de leucemia en la población infantil, y los existentes cuentan con un tamaño de muestra pequeño. En este estudio se reportan estadísticas descriptivas y se encuentran similitudes clínico-epidemiológicas con otras poblaciones.

Palabras clave: Leucemia cutis. Leucemia cutánea. Leucemia cutis pediátrica. Leucemia mieloide aguda.

\section{Introduction}

Leukemia is a neoplasm of the bone marrow and blood that is the primary malignant pathology in childhood. Acute leukemias are rapidly progressive diseases that affect immature hematopoietic cells, preventing them from functioning normally. The term acute myeloid leukemia (AML) encompasses a heterogeneous group of leukemias originating from myeloid, erythroid, and megakaryocytic precursors, and monocytic cell lineages. These leukemias are produced by clonal transformation of hematopoietic precursors by chromosomal rearrangements and multiple genetic mutations ${ }^{1}$. The classification and diagnosis of AML are based on morphological, cytochemical, cytogenetic, fluorescence in situ hybridization, immunophenotyping with flow cytometry, and molecular testing ${ }^{1}$. Therefore, the FAB (French-American-British Cooperative Group) classified AML into subtypes (M0-M7).

The clinical presentation of AML includes signs and symptoms caused by leukemic infiltration of the bone marrow and extramedullary sites such as the skin. Specific and nonspecific lesions can manifest cutaneous involvement during leukemia. Leukemides or nonspecific skin lesions are those lesions that do not contain tumor cells and may originate from abnormal hematopoiesis causing pancytopenia in the bone marrow. Their symptoms are bleeding, skin pallor, and susceptibility to infections; they are usually secondary to adverse drug reactions and paraneoplastic syndromes ${ }^{2}$. A low percentage of patients develop leukemia cutis (LC) or cutaneous leukemia, which is defined as cutaneous infiltration of neoplastic leukocytes (of myeloid or lymphoid lineage) resulting in skin lesions ${ }^{3,4}$. Cases that develop during the neonatal period are classified as congenital $L^{5}$. In some patients, cutaneous involvement is the only manifestation of leukemia, known as aleukemic leukemia cutis. Furthermore, this variety may precede leukemia in blood or bone marrow by months or years ${ }^{4,5}$.

Although acute lymphoblastic leukemia (ALL) is the most frequent leukemia in the pediatric population, LC appears more frequently in AML, mainly in the subtypes with a monocytic component ${ }^{6}$. So far, only a few studies of LC in the different varieties of leukemia have focused on the pediatric population, and the existing ones are case reports or studies with small sample size.

\section{Methods}

A retrospective cross-sectional study was conducted at the Hospital Infantil de México Federico Gómez from January 2009 to December 2019 to determine the clinical and demographic characteristics of AML patients with LC and other mucocutaneous manifestations.

All patients diagnosed with AML confirmed by bone marrow aspirate who attended the hospital during the referred study period and were younger than 18 years of age were included. Patients whose clinical records were not available or whose information was incomplete were excluded.

The medical information of AML diagnosed patients was obtained by reviewing the clinical records in the general archive of the hospital. Each patient's demographic and clinical data were collected, and the information obtained was captured in the statistical program SPSS version 17. Demographic information was collected from the initial clinical record. Clinical information (mucocutaneous manifestations) was obtained from the descriptions recorded in the clinical history, evolution, follow-up, and specialized assessment notes. Information was taken from the confirmation of the AML diagnosis until the evolution note of the patient's last visit to the hospital.

This study did not present any risk, since no intervention was performed; only medical record information was analyzed, preserving patient confidentiality.

\section{Results}

We identified 90 records of patients with a diagnosis of AML. From these records, 22 were excluded because 
Table 1. Dermatoses present in patients with leukemia cutis at the Hospital Infantil de México Federico Gómez

\begin{tabular}{|c|c|c|c|c|}
\hline Dermatological manifestation & Cases & Number of cases & Percentage (\%) & Clinical manifestations \\
\hline Leukemia cutis & 8 & $\begin{array}{l}6 \\
2\end{array}$ & $\begin{array}{l}75 \\
25\end{array}$ & $\begin{array}{l}\text { Leukemia cutis } \\
\text { Congenital leukemia cutis }\end{array}$ \\
\hline Paraneoplastic dermatoses & 10 & $\begin{array}{l}7 \\
1 \\
1 \\
1\end{array}$ & $\begin{array}{c}7 \\
10 \\
10 \\
10\end{array}$ & $\begin{array}{l}\text { Disseminated intravascular coagulation } \\
\text { Chronic ulcer } \\
\text { Paraneoplastic itch } \\
\text { Erythema nodosum }\end{array}$ \\
\hline $\begin{array}{l}\text { Chemotherapy-associated } \\
\text { dermatoses }\end{array}$ & 19 & $\begin{array}{c}16 \\
1 \\
1 \\
1\end{array}$ & $\begin{array}{l}84.5 \\
0.5 \\
0.5 \\
0.5\end{array}$ & $\begin{array}{l}\text { Alopecia or stomatitis/mucositis } \\
\text { Erythema multiforme } \\
\text { Anaphylaxis } \\
\text { Diffuse hyperpigmentation }\end{array}$ \\
\hline Infectious dermatoses & 29 & $\begin{array}{l}12 \\
7 \\
5 \\
1 \\
1 \\
1 \\
1 \\
1\end{array}$ & $\begin{array}{l}41 \\
24 \\
17 \\
0.3 \\
0.3 \\
0.3 \\
0.3 \\
0.3\end{array}$ & $\begin{array}{l}\text { Cellulitis } \\
\text { Cutaneous abscesses } \\
\text { Chickenpox/shingles } \\
\text { Folliculitis } \\
\text { Staphylococcal scalded skin } \\
\text { Ecthyma gangrenosum } \\
\text { Herpes simplex } \\
\text { Verruca vulgaris }\end{array}$ \\
\hline
\end{tabular}

they did not correspond to the diagnosis and were not available for review, and 14 were eliminated because they did not contain complete information.

We reviewed 54 files of patients with a diagnosis of AML who attended the hospital from 2009 to 2019, of which $29(53.7 \%)$ were males and 25 (46.3\%) females. The age of the patients ranged from 3 months to 18 years, with an average of 6 years 8 months. The cases studied came from ten states of the country: 23 cases $(42.6 \%)$ from the State of Mexico, $21(38.9 \%)$ from Mexico City, two cases (3.8\%) from Guerrero, two cases (3.8\%) from Veracruz and Tamaulipas, and one case per state from San Luis Potosí, Querétaro, Oaxaca, Jalisco, and Chiapas ( $1.8 \%$ for each case).

Of the total number of patients, $51(94.5 \%)$ received chemotherapy. Three $(5.5 \%)$ patients did not receive chemotherapy due to voluntary discharge or having medical insurance that allowed referral to another institution.

A skin lesion or dermatosis during the disease was present in $75.9 \%$ (41) of the patients, compared with $24.1 \%$ who showed no skin involvement. Thirteen patients presented two or more dermatoses during the disease, from which two cases were in the group with LC. The most frequent skin lesions were nonspecific; infectious conditions predominated, followed by dermatoses related to chemotherapy (Table 1). LC was present in $14.8 \%$ (8) of the patients, and two cases corresponded to congenital LC. The clinical and demographic characteristics of the patients with LC are shown in Table 2 (Figures 1-5). Table 3 shows the comparison between patients with and without skin infiltration.

\section{Discussion}

To the extent of our knowledge, the present study is the first study in Mexico to collect cases of $L C$ and other mucocutaneous manifestations over 10 years in all groups of pediatric patients with AML at a pediatric referral center. In this study, the most common mucocutaneous manifestations were drug reactions and infections.

There are few studies on LC in the Latino children population, and most are only case reports. Therefore, we could not compare the results with other populations with ethnic similarities with our population. When comparing our data with that from other parts of the world, only two studies of LC in patients with childhood AML

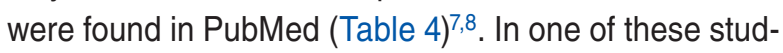
ies, the frequency of LC in children from France was found to be $5.5 \%$. In the adult population, an LC prevalence of $3.7-11 \%$ has been reported in patients with $A M L^{9,10}$. In our study, the frequency of LC was higher $(14.8 \%)$ and more closely resembled data reported in adults.

Regarding sex, LC was similar between males and females in children from the U.S. ${ }^{8}$, but in French children, 
Table 2. Clinical and demographic characteristics of patients with leukemia cutis at the Hospital Infantil de México Federico Gómez

\begin{tabular}{|c|c|c|c|c|c|c|c|c|c|}
\hline Case & Sex & Age & Birthplace & $\begin{array}{c}\text { AML } \\
\text { subtype }\end{array}$ & LC type & $\begin{array}{l}\text { Clinical } \\
\text { manifestation }\end{array}$ & $\begin{array}{l}\text { Time of onset relative } \\
\text { to the diagnosis of } \\
\text { systemic leukemia }\end{array}$ & HP & Evolution \\
\hline 1 & $\mathrm{~F}$ & $8 y$ & $\begin{array}{l}\text { Mexico } \\
\text { City }\end{array}$ & 2 & LC & $\begin{array}{l}\text { Gingival } \\
\text { hyperplasia } \\
\text { Chloromas }\end{array}$ & After & No & Monitoring \\
\hline 2 & $M$ & $7 y$ & $\begin{array}{l}\text { Mexico } \\
\text { City }\end{array}$ & 4 & LC & $\begin{array}{l}\text { Infiltrated } \\
\text { plaques }\end{array}$ & $\begin{array}{l}\text { During the diagnostic } \\
\text { assessment }\end{array}$ & No & Monitoring \\
\hline 3 & $M$ & $2 y$ & $\begin{array}{l}\text { Mexico } \\
\text { City }\end{array}$ & 7 & LC & Chloromas & $\begin{array}{l}\text { During the diagnostic } \\
\text { assessment }\end{array}$ & Yes & Monitoring \\
\hline 4 & $M$ & $8 \mathrm{~m}$ & $\begin{array}{l}\text { State of } \\
\text { Mexico }\end{array}$ & 2 & $\begin{array}{l}\text { Congenital } \\
\text { LC }\end{array}$ & $\begin{array}{l}\text { Papules } \\
\text { Infiltrated } \\
\text { plaques }\end{array}$ & $\begin{array}{l}\text { With the established } \\
\text { diagnosis }\end{array}$ & Yes & Treatment \\
\hline 5 & $\mathrm{~F}$ & $5 \mathrm{~m}$ & Veracruz & 0 & $\begin{array}{l}\text { Congenital } \\
\text { LC }\end{array}$ & $\begin{array}{l}\text { Nodules } \\
\text { Tumors }\end{array}$ & $\begin{array}{l}\text { With the established } \\
\text { diagnosis }\end{array}$ & Yes & Unknown \\
\hline 6 & M & $8 y$ & $\begin{array}{l}\text { State of } \\
\text { Mexico }\end{array}$ & 2 & LC & $\begin{array}{l}\text { Gingival } \\
\text { hyperplasia }\end{array}$ & $\begin{array}{l}\text { During the diagnostic } \\
\text { assessment }\end{array}$ & No & Treatment \\
\hline 7 & $\mathrm{M}$ & $2 y$ & Tamaulipas & 4 & LC & $\begin{array}{l}\text { Gingival } \\
\text { hyperplasia }\end{array}$ & $\begin{array}{l}\text { With the established } \\
\text { diagnosis }\end{array}$ & Yes & Treatment \\
\hline 8 & $M$ & $10 y$ & Guerrero & 0 & LC & $\begin{array}{l}\text { Infiltrated } \\
\text { plaques }\end{array}$ & $\begin{array}{l}\text { During the diagnostic } \\
\text { assessment }\end{array}$ & Yes & Death \\
\hline
\end{tabular}

AML, acute myeloid leukemia; LC, leukemia cutis; m, months; HP, histopathology; y, years.

Table 3. Characteristics of subjects with acute myeloid leukemia according to the presence of leukemia cutis

\begin{tabular}{|c|c|c|}
\hline Characteristics & $\begin{array}{c}\text { Patients with LC } \\
n(\%)\end{array}$ & $\begin{array}{c}\text { Patients with no LC } \\
\text { n (\%) }\end{array}$ \\
\hline Number of patients & 8 & 46 \\
\hline $\begin{array}{l}\text { Sex } \\
\text { Male } \\
\text { Female }\end{array}$ & $\begin{array}{l}6(75 \%) \\
2(25 \%)\end{array}$ & $\begin{array}{l}23(50 \%) \\
23(50 \%)\end{array}$ \\
\hline Age, median (range) & $\begin{array}{c}4-6 \mathrm{~m} \\
(1-4 \mathrm{~m} \text { to } 8 \mathrm{y})\end{array}$ & $\begin{array}{c}6 y \\
(3-11 \mathrm{~m} \text { to } 12 y)\end{array}$ \\
\hline $\begin{array}{l}\text { Type of AML according to FAB } \\
\text { M0: Minimally differentiated AML } \\
\text { M1: AML without maturation } \\
\text { M2: AML with maturation } \\
\text { M3: Acute promyelocytic leukemia } \\
\text { M4: Acute myelomonocytic leukemia } \\
\text { M5: Acute monocytic leukemia } \\
\text { M6: Acute erythroleukemia } \\
\text { M7: Acute megakaryoblastic leukemia }\end{array}$ & $\begin{array}{c}2(25 \%) \\
0 \\
3(37.5 \%) \\
0 \\
2(25 \%) \\
0 \\
0 \\
1(12.5 \%)\end{array}$ & $\begin{array}{c}1(2.2 \%) \\
10(21.8 \%) \\
11(24.0 \%) \\
10(21.8 \%) \\
8(17.3 \%) \\
0 \\
2(4.3 \%) \\
4(8.6 \%)\end{array}$ \\
\hline $\begin{array}{l}\text { Evolution } \\
\text { Treatment } \\
\text { Monitoring } \\
\text { Death } \\
\text { Unknown }\end{array}$ & $\begin{array}{l}3(37.5 \%) \\
3(37.5 \%) \\
1(12.5 \%) \\
1(12.5 \%)\end{array}$ & $\begin{array}{c}16(34.8 \%) \\
15(32.6 \%) \\
14(30.4 \%) \\
1(2.2 \%)\end{array}$ \\
\hline
\end{tabular}

$A M L$, acute myeloid leukemia; FAB, French-American-British Cooperative Group; LC, leukemia cutis; m, months; $y$, years. 


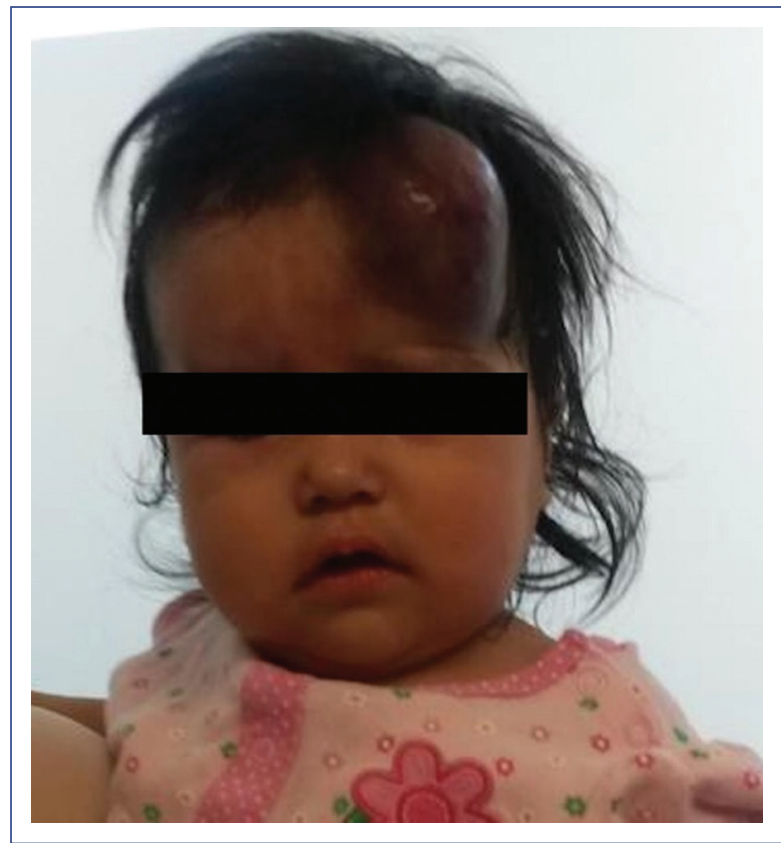

Figure 1. Right frontoparietal tumor secondary to leukemia infiltration.

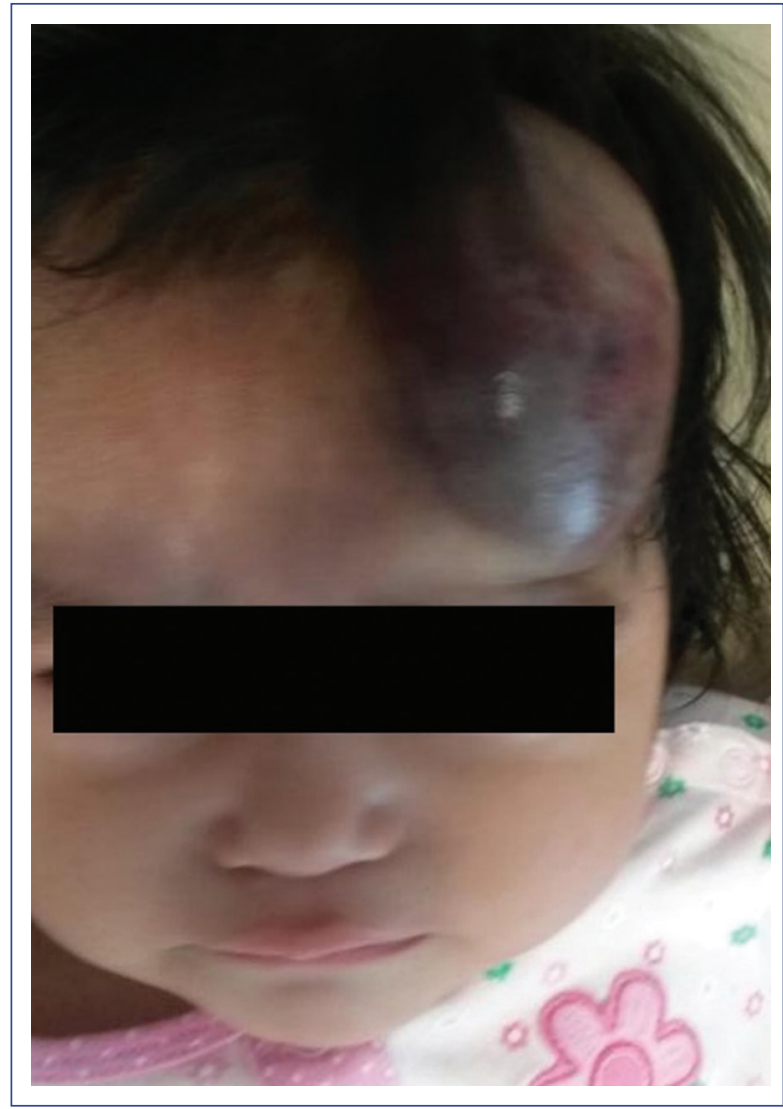

Figure 2. Close-up of the tumor.

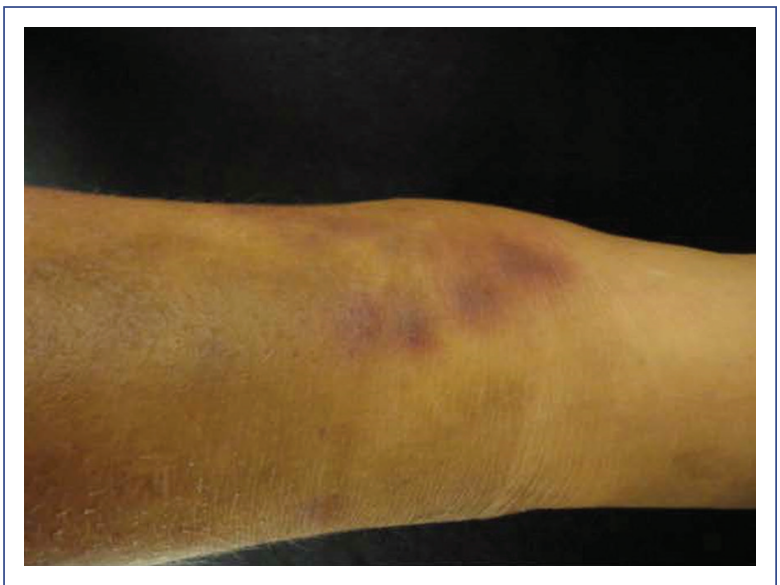

Figure 3. Infiltrated plaques.

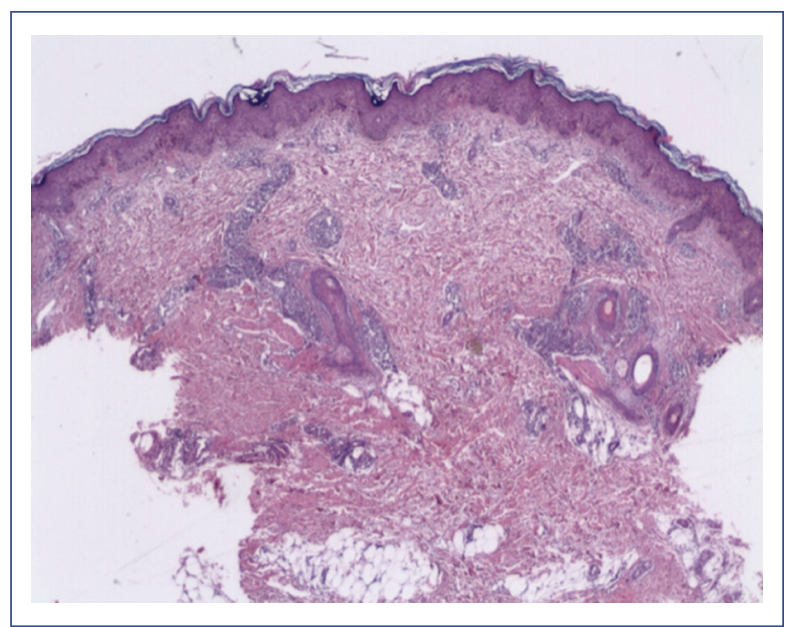

Figure 4. Perivascular, periannexal, and interstitial infiltrate consisting of atypical cells (hematoxylin and eosin staining).

LC predominated in males ${ }^{7}$. We also found that LC was more frequent in males in our study. As for age, children with $A M L$ with $L C$ were younger than children with $A M L$ but no LC; these data are similar to those reported by Gouache et al. in a French pediatric population?. Three pediatric studies included cases of neonates with AML and leukemic skin infiltration; the reported frequency at this age was $25-30 \%{ }^{11,12}$. Both American and Mexican studies confirmed this frequency.

To date, all reports in children and adults agree that the most frequent forms of clinical expression of LC are papules, nodules, and infiltrated plaques $7,8,13,14$. Our 
Table 4. Studies on leukemia cutis in the pediatric population

\begin{tabular}{|c|c|c|c|}
\hline Feature & $\begin{array}{l}\text { Present study } \\
\text { (Godínez et al.) }\end{array}$ & Andriescu et al. ${ }^{8}$ & Gouache et al. ${ }^{7}$ \\
\hline Country & Mexico & USA & France \\
\hline $\begin{array}{l}\text { Diagnoses of the study } \\
\text { population }\end{array}$ & AML & $\begin{array}{l}\text { AML (74.2\%), ALL, CMML, JMML, } \\
\text { MLL }\end{array}$ & AML \\
\hline Number of LC cases & $\begin{array}{l}\text { Total: } 8 \\
\text { Congenital LC: } 2\end{array}$ & $\begin{array}{l}\text { Total: } 31 \\
\text { Congenital LC: } 6\end{array}$ & $\begin{array}{l}\text { Total: } 24 \\
\text { Congenital LC: } 1\end{array}$ \\
\hline Sex & $\begin{array}{l}\text { F: } 25 \% \\
\text { M: } 75 \%\end{array}$ & $\begin{array}{l}\text { F: } 51.6 \% \\
\text { M: } 48.4 \%\end{array}$ & $\begin{array}{l}\text { F: } 29 \% \\
\text { M: } 71 \%\end{array}$ \\
\hline Frequency of LC & $\begin{array}{l}\text { Clinical } 14.8 \% \\
\text { Histological: } 9.2 \%\end{array}$ & - & $\begin{array}{l}\text { Clinical } 5.5 \% \\
\text { Histological: } 3.4 \%\end{array}$ \\
\hline $\begin{array}{l}\text { Age comparison } \\
\text { (average) }\end{array}$ & $\begin{array}{l}\text { With LC: } 4.7 \text { years } \\
\text { With no LC: } 7.2 \text { years }\end{array}$ & With LC: 321 days & $\begin{array}{l}\text { With LC: } 1.2 \text { years } \\
\text { With no LC: } 8.7 \text { years }\end{array}$ \\
\hline Clinical manifestations & $\begin{array}{l}\text { Infiltrated plaques: } 37.5 \% \text {. } \\
\text { Gingival hyperplasia: } 37.5 \% \text {. } \\
\text { Chloromas: } 25 \% \text {. } \\
\text { Papules: } 12.5 \% \text {. } \\
\text { Nodules: } 12.5 \% \\
\text { Tumors: } 12.5 \% \text {. }\end{array}$ & $\begin{array}{l}\text { Nodules: } 63.3 \% \\
\text { Papules: } 50 \%\end{array}$ & $\begin{array}{l}\text { Nodules: } 67 \% \text {. } \\
\text { Papules: } 8 \% \text {. } \\
\text { Papules + nodules: } 8 \% \text {. } \\
\text { Infiltrated plaques: } 17 \% \text {. }\end{array}$ \\
\hline Deaths & $\begin{array}{l}\text { Patients with LC: } 1(12.5 \%) \\
\text { Patients with no LC: } 14(30.4 \%)\end{array}$ & Patients with LC: 12 (38.7\%) & $\begin{array}{l}\text { Patients with LC: } 53 \% \\
\text { Patients with no LC: } 23 \%\end{array}$ \\
\hline
\end{tabular}

ALL, acute lymphoblastic leukemia; $A M L$, acute myeloid leukemia; CMML, chronic myelomonocytic leukemia; $F$, female; JMML, juvenile myelomonocytic leukemia; LC, leukemia cutis; M, male; MLL, mixed lineage leukemia or lymphoid-myeloid leukemia.

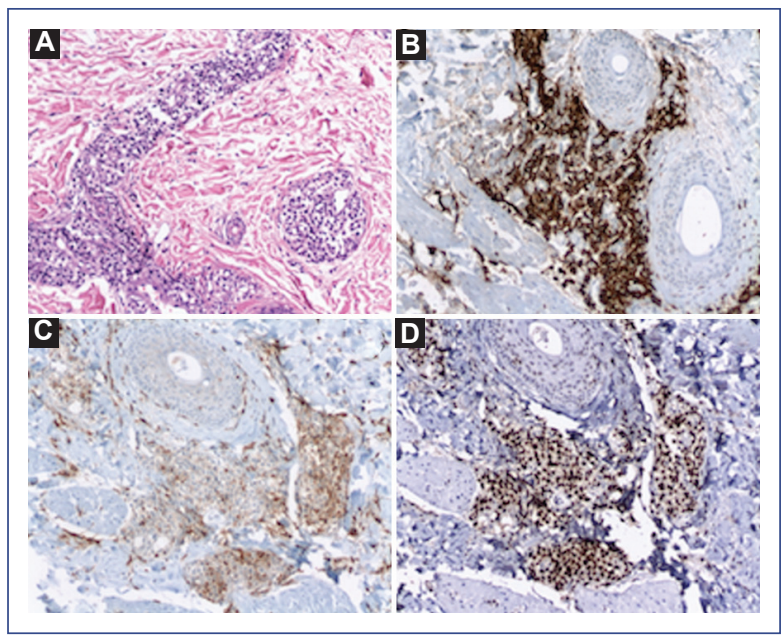

Figure 5. A: close-up of perivascular and interstitial infiltrate of atypical cells (hematoxylin and eosin staining). B: myeloperoxidase positive. C: CD68 (KP-1) positive. D: K1-67 (cell proliferation index) high.

patients also expressed these lesions. Additionally, some of them showed gingival hyperplasia, a mucosal condition very suggestive of leukemic infiltration that appears more in the myeloid cell lineage due to the monocyte's predilection to migrate to this tissue $e^{6,13,14}$. The other skin condition found was chloroma, which is a nodular, dome-shaped, firm, erythematous lesion that, when incised, acquires a greenish color due to its high myeloperoxidase content ${ }^{6,15}$; an increased incidence of these lesions has been observed in children ${ }^{6}$.

All skin lesions can appear at different stages of the hematologic disease. Most frequently, they occur after hematologic diagnosis $(55 \%)$, followed by coincident occurrence $(38 \%)$, and more rarely $(7 \%)$ before systemic infiltration ${ }^{13}$. In the pediatric population, the onset of LC usually occurs concomitantly and after systemic disease $^{8}$; this behavior was also observed in our study.

Finally, LC is considered by some authors as a poor prognostic factor because it may indicate tumor relapse or recurrence ${ }^{8}$. For example, in the study published by Su et al., $88 \%$ of adult patients with LC died, most of them within one year ${ }^{13}$. In French children, the cumulative mortality incidence in patients with $\mathrm{AML}$ and $\mathrm{LC}$ was higher $(53 \%)$ than patients without LC $(23 \%)^{7}$. These data are different from what we found in our study since there was only one death in LC cases $(12.5 \%)$ and mortality was higher in patients without LC $(30.4 \%)$. This observation could be explained due to the 
sample size or follow-up of patients at the study cutoff.

It is necessary to carry out more descriptive studies worldwide in the pediatric population with AML and LC to compare these populations' clinical and demographic characteristics and validate the results. We cannot generalize the information we obtained in this pediatric population with $\mathrm{AML}$ to a national level since most of the patients in our study were from Mexico City. Therefore, the information obtained is representative of only one geographic region. Some of the remaining questions for this topic are whether chloromas in LC are more frequent in children and if the appearance of LC modifies the prognosis in pediatric patients. To answer these questions, we need to have a more extensive series of patients with a longer follow-up time.

Our study found that $L C$ in patients with $A M L$ appeared in $14.8 \%$ of cases (and $9.2 \%$ with histological correlation). Of the cases with LC, the predominant gender was male, the patients were younger than those without LC, and the most frequent $A M L$ subtype was M2 (37.5\%); infiltrated plaques, chloromas, and gingival hyperplasia were the most frequent clinical expressions, and the time of onset of LC was simultaneous with the diagnosis of AML $(50 \%$ in the diagnostic workup, $37.5 \%$ with the diagnosis established) or after diagnosis.

AML can present with infiltration of neoplastic leukocytes to the skin, and its clinical expression is variable. Some lesions are infiltrated papules, nodules, or plaques and can be the first sign of disease or be indicative of clinical progression; their recognition will favor a timely diagnosis and treatment.

\section{Ethical disclosures}

Protection of human and animal subjects. The authors declare that no experiments were performed on humans or animals for this study.
Confidentiality of data. The authors declare that they have followed the protocols of their work center on the publication of patient data.

Right to privacy and informed consent. The authors have obtained the written informed consent of the patients or subjects mentioned in the article. The corresponding author has this document.

\section{Conflicts of interest}

The authors declare no conflict of interest.

\section{Funding}

None.

\section{References}

1. Rubnitz JE, Gibson B, Smith FO. Acute myeloid leukemia. Pediatr Clin North Am. 2008;55:21-51.

2. Martínez-Leboráns L, Victoria-Martínez AM, Torregrosa-Calatayud JL, Alegre de Miquel V. Leukemia cutis: a report of 17 cases and a review of the literature. Actas Dermosifiliogr. 2016;107:e65-9.

3. Cho-Vega JH, Medeiros LJ, Prieto VG, Vega F. Leukemia cutis. Am J Clin Pathol. 2008;129:130-42.

4. Vishalakshi V, Torsekar RG, Shinde S. Aleukemic leukemia cutis. Indian J Dermatol Venereol Leprol. 2007;73:109-11.

5. Torrelo A. Dermatología en pediatría general. Madrid: Aula Médica; 2008. pp. 497-8.

6. Wagner G, Fenchel K, Back W, Schulz A, Sachse MM. Leukemia cutisepidemiology, clinical presentation, and differential diagnoses. J Dtsch Dermatol Ges. 2012;10:27-36.

7. Gouache E, Greze V, Strullu M, Saultier P, Fenneteau O, Gandemer V, et al. Leukemia cutis in childhood acute myeloid leukemia: epidemiological, clinical, biological, and prognostic characteristics of patients included in the ELAM02 study. Hemasphere. 2018;2:1-3.

8. Andriescu EC, Coughlin CC, Cheng CE, Prajapati VH, Huang JT, Schmidt BA, et al. Pediatric leukemia cutis: a case series. Pediatr Dermatol. 2019:36:658-63.

9. Boggs DR, Wintrobe MM, Cartwright GE. The acute leukemias. Analysis of 322 cases and review of the literature. Medicine (Baltimore). 1962;41:163-225.

10. Agis $\mathrm{H}$, Weltermann $\mathrm{A}$, Fonatsch $\mathrm{C}$, Haas $\mathrm{O}$, Mitterbauer $\mathrm{G}$, Müllauer L, et al. A comparative study on demographic, hematological, and cytogenetic findings and prognosis in acute myeloid leukemia with and without leukemia cutis. Ann Hematol. 2002;81:90-5.

11. Roberts I, Fordham NJ, Rao A, Bain BJ. Neonatal leukaemia. Br J Haematol. 2018;182:170-84.

12. Resnik KS, Brod BB. Leukemia cutis in congenital leukemia. Analysis and review of the world literature with report of an additional case. Arch Dermatol. 1993;129:1301-6.

13. Su WP, Buechner SA, Li CY. Clinicopathologic correlations in leukemia cutis. J Am Acad Dermatol. 1984;11:121-8.

14. Ratnam KV, Khor CJL, Su WPD. Leukemia cutis. Dermatol Clin. 1994:12:419-31.

15. Blázquez-Sánchez N, Fernández $\mathrm{Cl}$, Cardeñoso $\mathrm{AE}$. Leucemia cutánea. Piel. 2002;17:310-5. 